\title{
The development of Iqra' Lampung script teaching materials for primary school levels in Bandar Lampung city
}

\author{
Ali Imron ${ }^{1}$ \\ ${ }^{1}$ Department of History Education, University of Lampung, Bandar Lampung, Indonesia
}

\begin{abstract}
The Lampung Provincial Government requires all primary and secondary schools to provide Lampung language lessons and introduction to Lampung script. Some students only recognize the Lampung Khaganga script, which amounts to 20 characters, while the combination of the main character and 12 characters that produces 560 syllables of the Lampung script is not yet fully understood. In fact, knowledge of Lampung script is still lacking, even some students do not understand Lampung script, it can be said that learning Lampung script at elementary school level has not been successful. This could be due to a lack of modules (teaching materials) that support learning. The research aims to develop Lampung language teaching materials in Lampung script material in the form of Iqra' Lampung script as teaching material for elementary school level. This study adopted a research and development (R\&D) method proposed by Gall, Borg \& Gall (2007). The work step procedure includes: 1) preliminary study, 2) product development, 3) product validation test and revision. Based on the research that has been done, it can be concluded that the teaching material (module) is feasible because the average value is 4.588 from the teacher validator and 4.446 from the lecturer validator. If it is based on a scale of 5 it can be concluded that the Iqra' Lampung script teaching material has a very good value of teachers and good grades from expert lecturers in terms of material aspects, language, presentation, the effect of teaching materials on learning strategies, and overall appearance feasibility. Modules are basically teaching materials that are systematically using language that is easily understood by students according to their level of knowledge and age so that they can learn independently or without minimal guidance from teachers.
\end{abstract}

\section{KEYWORDS}

Language; Lampung script: learning; teaching material; primary school

Received: 31 January 2021

Accepted: 3 February 2021

Published: 4 February 2021

\section{Introduction}

Indonesia is a country that is rich in cultural diversity, one form of cultural diversity is languages that are different in each region (Nama, Pamungkas, \& Septama, 2019). Lampung culture is part of Indonesian culture which has its own characteristics and is different from other cultures in other regions in Indonesia, such as the use of the Lampung script. The Lampung Khaganga script is an orthographic system produced by local communities which includes a script and a literacy system for writing local languages (Muhammad, 2017).

\footnotetext{
CONTACT Ali Imron (M) ali.imron@fkip.unila.ac.id 
Nowadays, Lampung Province is no longer dominated by native people of Lampung. Many migrants from outside Lampung Province live in Lampung Province. This causes the indigenous people of Lampung to rarely use the Lampung language and script as a means of daily communication (Kurnia, Handayani, Wira, \& Maulini, 2019). As a form of cultural preservation, especially Lampung culture, Lampung script is taught in all elementary and secondary schools in Lampung. The Lampung Provincial Government requires all primary and secondary schools to provide Lampung language subjects to all their students. The Lampung language teacher has an obligation to provide an understanding of the Lampung script and its use in everyday life (Nama \& Arnoldi, 2016).

Lampung Provincial Regulation Number 2 of 2008 concerning Maintenance of Lampung Culture and Governor Regulation Number 39 of 2014 concerning Preservation and Learning of the Lampung Language as a mandatory subject that is included in local content. Therefore, every school with the existence of regulation number 39 of 2014 is obliged to teach the language and arts of Lampung to their students without exception. The implementation of the Governor Regulation Number 39 of 2014 seems to be able to have quite a positive impact. Through this policy, students who are members of non-Lampung ethnic groups will be able to know and understand both the language and culture of Lampung (Hartono, Pitoewas, \& Yanzi, 2016).

The position of the Lampung language in learning in schools as a local content aims to provide knowledge, skills, and behaviour to students in order to have the insights in the area where they live by developing students' communication skills and abilities using the Lampung language, increasing sensitivity and appreciation of literary works Lampung, and fostering responsibility for preserving the results of Lampung cultural creations as a part of national culture. The Lampung Provincial Government requires all primary and secondary schools to provide Lampung language subjects to their students, including the introduction of Lampung script (Mulyanto \& Prasetyawan, 2018). Students from primary school to high school grades are expected to have the ability to read and write Lampung script. Especially at the basic education level, Lampung script is a provision of knowledge for higher school levels. Many students for the elementary school level argue that this material is difficult to learn. This can be based on the fact that elementary school-aged children are new to alphabets and are not familiar with other letters such as the Lampung script. Letters that are different from the letters of the alphabets are commonly used by most people in everyday life. Thus, it can be said that it is natural that the Lampung script material is difficult for students to understand.

Some students only recognize the Lampung Khaganga script, which amounts to 20 types of characters, while the combination of the parent character and 12 children that produces 560 syllables of the Lampung script is not fully understood by students. The survey results from Febriana's (2012) research show that of the 30 correspondents, 7.1\% know and 92.9\% do not know Lampung script. In fact, the students' knowledge of Lampung script is still very lacking, even some students do not understand Lampung script. It can be said that the Lampung script learning at elementary school level has not been successful. This could be due to the lack of modules (teaching materials) that support Lampung script learning. The Lampung language (Lampung script) materials are not available for teaching and learning yet (Nurfeni, Sutarsyah, \& Munaris, 2017).

Each subject requires teaching materials to deliver. Teaching materials in this learning make it easier for teachers and students to carry out learning and teaching activities in classrooms. An example is in Lampung local language lessons with Lampung script material. This teaching material is needed to solve the problems faced by teachers and students. The teaching material aims to make Lampung script material conveyed effectively, so that students can more easily understand Lampung script material as delivered by the teacher.

Teaching materials are intended to facilitate teachers and students during the learning process. For teachers, teaching materials can be combined with learning methods so that they can master class and subject matter that is conveyed to students properly. However, in reality there are still many teachers who lack knowledge of Lampung script material. This is because the teacher is not purely a graduate of the Lampung language department. The absence of Lampung 
language teachers graduating from Lampung language department study program makes Lampung language lessons carried out based on the original Lampung ethnic group so that they do not understand the Lampung script material (Hartono et al., 2016). This condition has an ineffective impact on Lampung script learning at the elementary school level. Teachers only carry out learning with a traditional teacher-centred model and do not use media or innovative material development. Teachers and students only depend on the use of textbooks and the available worksheets, so that books devoted to teaching materials for Lampung script are limited in number.

Based on these problems, learning innovation is needed to provide solutions through a practical and simple Lampung script learning process that can be applied to children. Adopting research conducted by Wijayanti (2006 as cited in Haryanto, 2013) regarding Javanese Script Learning through the Iqra method, this study developed Lampung script teaching materials in the form of the book Iqro' (Arabic letters), because of its effectiveness and success. The concept of the method of Iqra 'in the concept of literacy is learning to read starting from the simplest things from syllables to words then to sentences. The Iqra 'method is a method of reading the Qur'an which emphasizes directly on reading practice, while the Iqra' guidebook consists of 3 volumes starting from a simple level, step by step to a perfect level. Each volume has teaching instructions with the aim of making it easier for each student who will use it, as well as for educators who will apply the method to their students. The Iqra 'learning method which is applied to the learning and teaching process of the Lampung script or called "Iqra" the Lampung script "consists of three volumes with the Lampung script arrangement composed of volumes I, II, and III. The Iqra method 'is one of the methods that are familiar to the public because this method is commonly used by Indonesians (Rahmawati, 2016). With this bound reading method, it is hoped that it can be a solution to the difficulties of learning Lampung script at the level of elementary school students.

\section{Literature review}

\section{Lampung language and literacy}

Teaching Materials are all forms that are used to assist teachers/instructors in carrying out teaching and learning activities in the classroom. The material in question can be in the form of written material or unwritten material. Teaching materials are a set of materials that are systematically arranged in written and unwritten so that an environment/atmosphere is created that allows students to learn (Hartono \& Puspitasari, 2013). Teaching the Lampung language which contains the Lampung script is a local content that must be taught in all primary and secondary schools in Lampung Province. Teaching the Lampung language requires teaching materials aimed at making it easier for teachers and students during the learning process. Teaching local languages is important to get to know one's identity more deeply (Gyamtso \& Maxwell, 2012). Lampung language teaching is given to students with the aim that students are able to express themselves freely in language using the Lampung language either dialect ' $\mathrm{A}$ ' or dialect 'O' (Nurfeni et al., 2017). The Lampung language with the Api Dialect (Saibatin) is the language used by coastal communities, meanwhile, the Nyow dialect (Papadun) is the language used by the people of Lampung in non-coastal areas. Thus, the Lampung language is a local language spoken by Lampung communities and is also the identity of the Province of Lampung (Putri, 2018).

\section{Iqra' Lampung script}

Iqra' Lampung script, also known as had Lampung, is a writing that was used as a communication tool for the people of Lampung in ancient times. Lampung script is generally called khaganga, because the first three letters of the script sound like this (ka-ga-nga). Khaganga is used to write a sign or code, mantra, and other important letters, done by a scribe with stunning handwriting skills (Budiman et al., 2019). Lampung script is influenced by two elements, namely the Pallava script and Arabic letters which have 20 characters and 12 additional symbols (Kuipers, 2003). Had Lampung is related to the Rencong script, Bengkulu script, Sundanese script, 
and Lontara script (Aryantio \& Munir, 2015). Had Lampung, which is related to the Pallava script from South India, has phonetic writing with syllables which are vowels such as Arabic letters. Because the nature of the Lampung script and the Arabic script have is almost the same in terms of principles, the teaching material that can be developed for learning the Lampung language is Iqra' Lampung script. Through the Iqra' Lampung script, students are expected to be more fluent in memorizing the accompanying articles. Mulyana (2017 as cited in Istiningsih \& Martinah, 2016) affirms that the Iqra' method is reading fluency with syllabic, which is per syllable.

\section{Methods}

This study aims to produce Lampung language teaching materials, especially Lampung script in the form of Iqra' to assist teachers in guiding students and students to learn independently about Lampung script material. This research was carried out through educational research and development. Thus, the research design used was the research and development design of Borg and Gall (1983, p. 95). The product development carried out includes 10 stages of activity. Borg and Gall's research and development model was then adapted in this study into three stages of research, namely: (1) preliminary study and model (product) development; (2) limited testing which includes expert validation and small-scale testing of products in the form of prototype teaching materials for Iqra' Lampung script; and (3) testing on the actual class. The research steps were as follows: (1) the first stage, conducting a preliminary study by applying a qualitative descriptive approach; (2) the second stage includes the prototype 1 product test stage which includes the teaching material expert test, content testing, and small-scale trials by elementary students, and; (3) the third stage, material testing teach the Lampung Iqra' script (product prototype 2) through a quasi-experimental design (pre-test - post-test non-equivalent control group design).

This research was conducted in elementary schools (SD) in the city of Bandar Lampung using a purposive sampling technique. The study employed questionnaires, interview guides, multiple choice test questions, observation sheets and validation sheets as research instruments. The collected data were analysed through Descriptive qualitative analysis and quantitative Descriptive Analysis, categorization using the N-Gain test, and ANOVA statistical test on student learning outcomes.

\section{Results and discussion}

Table 1. Material expert assessment from the teacher

\begin{tabular}{clcc}
\hline No & \multicolumn{1}{c}{ Assessment Aspects } & Mean & Category \\
\hline $\mathbf{1}$ & Contents & 4.3 & Good \\
$\mathbf{2}$ & Language & 4.67 & Very Good \\
$\mathbf{3}$ & Presentation & 4.3 & Good \\
$\mathbf{4}$ & Media effect on learning strategy & 4.67 & Very Good \\
$\mathbf{5}$ & Overall appearance feasibility assessment & 5 & Very Good \\
\hline
\end{tabular}

Based on the results of data analysis in this study, the results of the validation of the material expert from the teacher on the Iqra' Lampung script teaching material in primary school for the assessment of the feasibility of the material aspects have a total value of 43 or 4.3 on average is 4.3. When converted based on a scale of 5 it is declared good, and for the assessment of the feasibility assessment for the linguistic aspect has a total value of 14 (4.67 on average) and if converted based on a scale of 5 it is declared very good. The feasibility assessment of the presentation aspect has a total value of 13 (4.3 on average) and if it is converted based on a scale of 5 then it is stated good. The assessment of the media effect aspect learning strategy has a total value of 14 (4.67 on average) and if it is converted based on a scale of 5 then it is declared very good. The assessment of the comprehensive appearance feasibility has a total value of 10 (5 on average) and when converted into scale a 5 then it is declared very good. Overall, the evaluation of 
material experts (teachers) on the developed teaching materials can be stated very well so that it can be applied in the learning process after being corrected based on input from material experts (teachers) in the form of improvements in the field of presentation of Iqra' Lampung script teaching materials. improvement.

Table 2. Material expert assessment from the lecturer

\begin{tabular}{clcc}
\hline No & \multicolumn{1}{c}{ Assessment Aspects } & Mean & Category \\
\hline $\mathbf{1}$ & Contents & 4.4 & Good \\
$\mathbf{2}$ & Language & 4.3 & Good \\
$\mathbf{3}$ & Presentation & 4.3 & Good \\
$\mathbf{4}$ & Media effect on learning strategy & 4.67 & Very Good \\
$\mathbf{5}$ & Overall appearance feasibility assessment & 4.5 & Very Good \\
\hline
\end{tabular}

The data analysis in Table 2 above also shows the validation results of the material experts from the lecturers on the Iqra' Lampung script teaching materials in primary school for the assessment of the feasibility of the material aspect have a total value of 44 (4.4 on average) and if converted based on a scale of 5 it is declared good. The Feasibility assessment for the linguistic aspect has a total value of 13 (4.33 on average) and if it is converted based on a scale of 5 then it is declared good. The feasibility assessment of the presentation aspect has a total value of 13 (4.3 on average) and if it is converted based on a scale of 5 then it is declared good. Regarding the assessment of media effect aspect on learning strategy, it has a total value of 14 (4.67 on average) and if it is converted based on a scale of 5 it is declared very good. The assessment of the overall appearance feasibility has a total value of 9 (4.5 on average) and if converted based on a scale of 5 then it is declared very good. Overall, the evaluation of material experts (lecturers) on the developed teaching materials can be stated very well so that it can be applied in the learning process after revision according to the input from material experts (lecturers) in the form of improved instructions in each volume so that it is easily understood by students.

In this Iqra' Lampung script teaching material development research, after a validation test was carried out by material experts from both university lecturers and school teachers who carried out learning in the field, it was found that the teaching material (module) was feasible because it obtained an average value of 4.588 from teacher validators and 4.446 from lecturer validators. If based on a scale of 5 , it can be stated that the Iqra' Lampung script teaching material has very good scores from the teacher and good grades from expert lecturers in the material aspect, linguistic aspect, presentation aspect, aspect of the effect of teaching materials on learning strategies, and overall appearance.

The Iqra' Lampung script teaching materials was arranged using the binding reading method. It is hoped that this can be a solution to overcome the difficulties of Lampung script teaching and learning at elementary school level. According to Nilasari et al. (2016), the modules are basically teaching materials that are systematically arranged using a language that is easily understood by students according to their level of knowledge and age so that they can learn independently or without minimal guidance from teachers. Therefore, students are expected to be able to understand well the teaching materials (modules) developed in this study because the modules have been arranged in accordance with language that is easily understood by elementary school level students. In addition to language that is easy to understand, it is also arranged according to the age of students.

\section{Conclusion}

Based on the results and discussion above, it can be concluded that the teaching materials (modules) developed in the current study are feasible with an average score of 4.588 from teacher validators and 4.446 from lecturer validators. If based on a scale of 5 it can be concluded Iqra' Lampung script teaching materials have very good grades from teachers and good grades from expert lecturers in material aspects, linguistic aspect, presentation aspect, aspect of the effect of teaching materials on learning strategies, and overall appearance feasibility. However, this study 
also has its own limitations. Therefore, future studies on the development of Iqra' Lampung script teaching materials through digitization to test the effectiveness of Iqra' Lampung script teaching materials in schools are needed to be taken into account.

\section{Acknowledgements}

I would like to express my gratitude to Ms. Mery Rakhmawani, S.Pd as a material expert from SDN 3 Rajabasa Bandar Lampung and also Dr. Farida Aryani, M.Pd as a material expert who did the validation or evaluation of the Iqra' Lampung script material product for elementary schools in Bandar Lampung. In addition, my gratitude also goes to the reviewers for providing constructive comments on the earlier version of this paper.

\section{Funding}

This research received a grant of DIPA BLU, University of Lampung, 2020.

\section{References}

Aryantio, A., \& Munir, R. (2015). Pengenalan aksara Lampung menggunakan jaringan syaraf tiruan. Konferensi Nasional Informatika (KNIF), 34-38.

Budiman, A., Wijaya, P. W., Nur, M. H. A., Halawa, M. V., \& Susyanti, S. (2019). Revisualisasi aksara Kaganga sebagai identitas Lampung. Jurnal Bahasa Rupa, 2(2), 118-125. https://doi.org/10.31598/bahasarupa.v2i2.344

Febriana, P., Dayawati, R. N., \& suliiyo, m. d. (2012). aplikasi pengenalan aksara Lampung pada teknologi berbasis touchscreen. Bandung.

Gall, M.D., Gall, Joyce P., \& Borg, Walter R. (2007). Educational research: An introduction. New York: Pearson

Gyamtso, D., \& Maxwell, T. W. (2012). Present practices and background to teaching and learning at the Royal University of Bhutan (RUB): A Pilot Study. International Journal of Teaching and Learning in Higher Education, 24(1), 65-75.

Hartono, H., Pitoewas, B., \& Yanzi, H. (2016). Peranan mulok bahasa Lampung dalam upaya pelestarian bahasa dan budaya Lampung. Jurnal FKIP Unila, 4(3).

Hartono, Y., \& Puspitasari, E. (2013). Pengembangan bahan ajar mata kuliah sejarah Madiun berbasis $\begin{array}{llll}\text { kemandirian } & \text { belajar } & \text { mahasiswa. } & \text { Agastya, }\end{array}$ https://doi.org/10.1017/CBO9781107415324.004

Haryanto, A. (2013). Peningkatan keterampilan membaca huruf Jawa melalui metode Iqra' pada siswa kelas IV SD Negeri II Krisak Kecamatan Selogiri tahun ajaran 2011/2012. Universitas Muhammadiyah Surakarta.

Istiningsih, G., \& Martinah. (2016). Pengembangan media Iqra Semar untuk peningkatkan keterampilan membaca huruf Jawa siswa SD kelas IV. Jurnal Penelitian \& Artikel Pendidikan, 8(1), 27-33.

Kuipers, J. (2003). Indic scripts of insular Southeast Asia: Changing structures and functions. Tokyo.

Kurnia P, A., Handayani, D., Wira A, M. A., \& Maulini, R. (2019). Aplikasi pembelajaran aksara Lampung berbasis Android. Retrieved from http://eprints.jeb.polinela.ac.id/id/eprint/439

Muhammad, M. A. (2017). Mobile dictionary aksara Lampung berbasis teknologi spa (single webpage application). Electrician (Jurnal Rekayasa Dan Teknologi Elektro), 11(2), 66-71.

Mulyanto, A., \& Prasetyawan, P. (2018). Rancang bangun game edukasi "Matching Aksara Lampung" berbasis smartphone Android. Journal of Computer Engineering System and Science (CESS), 3(1), 36-44.

Nama, G. F., \& Arnoldi, F. (2016). Rancang bangun aplikasi game edukasi pembelajaran aksara Lampung "Ajo dan Atu - Belajar Aksara Lampung" berbasis Android dengan sistem multi-ending menggunakan engine ren'py. Jurnal Teknologi Informasi Dan Ilmu Komputer, 3(4), 238. https://doi.org/10.25126/jtiik.201634211

Nama, G. F., Pamungkas, A. D., Septama, H. D., Informatika, T., Lampung, U., Elektro, T., \& Lampung, U. (2019). Rancang bangun aplikasi game edukasi koleksi permainan aksara Lampung (Koper Apung) berbasis Android menggunakan design and development of educational game " Koleksi Permainan Aksara Lampung ( Koper Apung )" Based on Android Using Scrum. Jurnal Teknologi Informasi Dan Ilmu Komputer (JTIIK), 6(4). https://doi.org/10.25126/jtiik.201961096

Nilasari, Efi, dkk. 2016. Pengaruh penggunaan modul pembelajaran kontekstual terhadap hasil belajar siswa kelas v sekolah dasar. Jurnal Pendidikan, 1(7), 1399-1404.

Nurfeni, Sutarsyah, C., \& Munaris. (2017). Pengembangan Modul Pembelajaran Bahasa Lampung Berbasis Teks Kelas VIII Semester Ganjil. Jurnal Tiyuh Lampung, 1(1), 1-9.

Putri, N. W. (2018). Pergeseran bahasa daerah Lampung pada masyarakat kota Bandar Lampung. PRASASTI: Journal of Linguistics, 3(1), 83. https://doi.org/10.20961/prasasti.v3i1.16550

Rahmawati, R. D. (2016). Metode bacaan berjilid untuk mengatasi kesulitan membaca aksara Jawa siswa sekolah dasar. Proseding Seminar Nasional PGSD UPY, 111-120. Yogyakarta: Universitas PGRI Yogyakarta. 